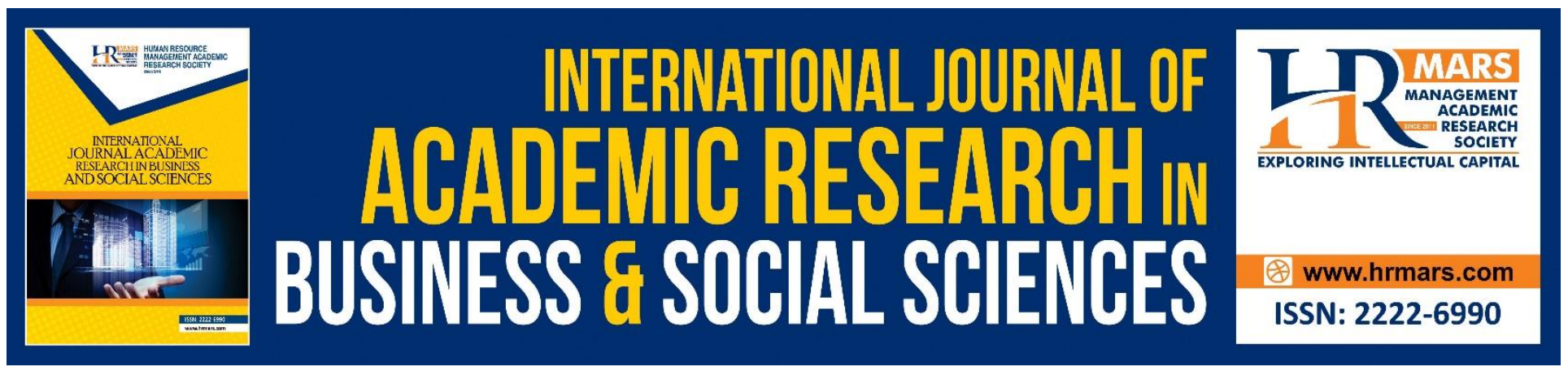

\title{
Using Creativity Tools to Achieve Advertising effectiveness in Organizations
}

\author{
Mbah, Chukwuemeka Chris, Nwatu, Chibuike Basil, Okafor, Ozoemena \\ Christian
}

To Link this Article: http://dx.doi.org/10.6007/IJARBSS/v8-i7/4432

DOI: $\quad 10.6007 /$ IJARBSS/v8-i7/4432

Received: 24 May 2018, Revised: 19 June 2018, Accepted: 29 June 2018

Published Online: 08 July 2018

In-Text Citation: (Mbah, Nwatu, \& Okafor, 2018)

To Cite this Article: Mbah, C. C., Nwatu, C. B., \& Okafor, O. C. (2018). Using Creativity Tools to Achieve Advertising effectiveness in Organizations. International Journal of Academic Research in Business and Social Sciences, 8(7), 887-901.

\section{Copyright: (C) 2018 The Author(s)}

Published by Human Resource Management Academic Research Society (www.hrmars.com)

This article is published under the Creative Commons Attribution (CC BY 4.0) license. Anyone may reproduce, distribute, translate and create derivative works of this article (for both commercial and non-commercial purposes), subject to full attribution to the original publication and authors. The full terms of this license may be seen

at: http://creativecommons.org/licences/by/4.0/legalcode

Vol. 8, No. 7, July 2018, Pg. 887 - 901

http://hrmars.com/index.php/pages/detail/IJARBSS

JOURNAL HOMEPAGE

Full Terms \& Conditions of access and use can be found at http://hrmars.com/index.php/pages/detail/publication-ethics 


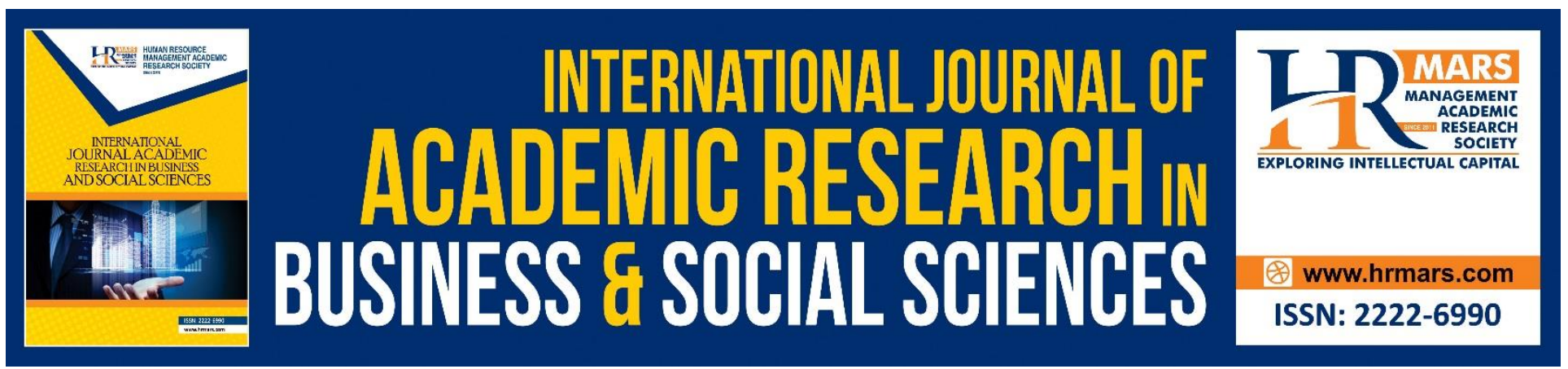

\title{
Using Creativity Tools to Achieve Advertising effectiveness in Organizations
}

\author{
Mbah, Chukwuemeka Chris Ph.D. \\ Department of Marketing, Enugu State University of Science and Technology, Enugu State.
}

Nwatu, Chibuike Basil

Department of Marketing, Nnamdi Azikiwe University, Anambra State.

\section{Okafor, Ozoemena Christian}

Department of Marketing, Enugu State University of Science and Technology Enugu State.

Corresponding Author: Peter.Ozoemena@yahoo.com

\begin{abstract}
This study access using creativity tools to achieve Advertising Effectiveness in Organizations. The major objective of this study was to examine how to use best creativity tools to achieve advertising effectiveness in organizations, specific objectives includes determining the influence of brainstorming on achieving advertising effectiveness: To examine the impact of Humor in achieving Advertising Effectiveness. The design of the study was descriptive survey with a sample size of 89 subjects randomly selected, A Structural Questionnaire was the Instrument used to gather Data from the field for Analysis; Multivariate Regression was employed to rest the four hypotheses formulated. The findings revealed that the influence of brainstorming on achieving advertising in organization were greater than the influence of Humor, Novelty and creativeness (58.34>23A1 and 12.074) respectively. The study concluded that organization should strengthen on these two major that yield the highest value for achieving advertising effectiveness in organizations. The study recommended among others that the model used in this work should, be properly adopted by the firm's for adequate sustainability of its existence.
\end{abstract}

Keywords: Creativity Tools, Advertising Effectiveness, Organizations.

\section{Introduction}

Creativity is considered as the ultimate aspect of human qualities central to people from all walks of life, and even as one of the measures of intelligence. Our ability to create is believed to be God like. A gift from the God's", as the author of Amadens says. Successful creativity management is the hallmark of a vital and prosperous advertising Agency. The most important function of an Agency is designing creative advertisement (Tellis, 1998). It is the only organizational instance in which 
INTERNATIONAL JOURNAL OF ACADEMIC RESEARCH IN BUSINESS AND SOCIAL SCIENCES Vol. 8, No. 7, July 2018, E-ISSN: 2222-6990 @ 2018 HRMARS

creativity is the name of a department needed creative directives. Creative through is so valuable in advertising agencies that entire business structure are sometimes designed around the talents of one "creative genius" (Cummings, and Oldham, 2013). Creativity in general represents important criteria in selecting advertising agencies. It is an important predictor of overall satisfaction within an agency (Halinen, 1997, West, 1993).

Creativity is the heart and soul of advertising service (Halinen, 1997). "The world creative" is the current with advertising agencies (Ardeii, 2004). Likewise creativity has remained almost unexplored in the area of advertising (Kover 1995, and Stewart 1992). In this sense, creativity advertisement are considered as an effective tool to break through the media cluster reach to customer minds, build an impression that lead to greater effectiveness of advertising campaign in organizations (Angel et al 2007). Organization use creativity advertising as an instrument to enhance organizational brand interest, sales volume, brand attitude, customer satisfaction, purchase intentions, Firm's expansion and image identification of the organization. Then advertising effectiveness obligated to information awareness, persuasion, retaining customer memorizing and educating customer about the existing product. Mean while to remain as competitive organization, there is need for developing creativity tool such as brainstorming, novelty, meaningfulness, humor, positiveness, craftiness, comedy, drama, conflict resolution, stronger, Theme, sources, product, and colour etc. Activity involved in place of novel and suitable product, messages, processes and approaches (Shelley and Gilson 2004).

Creativity is very crucial in advertising sector. Most advertising campaigns fail because of lack of creativity tools adoption. The major problem of this study is to identify those factors that could lead to standard application of creativity tools in advertising, in other words, most business owners don't believe in advertising, but there is need with critical evidence to show on how business owner avoid advertisement. Creativity is one of the sure ways of avoiding social irresponsibility and unethical conducts in advertising (Aliede, 2005). Conceptual space of creativity lack many significant literatures in advertising research, only few studies deal explicitly with creativity (Zinkha, 1993). Among these, few have produced results that are both significant and unambiguous. The technological Advancement has brought very big challenge facing creativity activities in organization, based on that of constant change and unpredictable growth of equipment application used improving advertising forces (Mathew and Ibikunce, 2012). Therefore, it is against this backdrop the study intends to examine how to use creativity tools to achieve advertising effectiveness in organizations. The study also captured other specific sub sections such review of related literature, methodology, findings, conclusion and recommendations.

\section{Objectives of the Study}

The major objective of this study is to examine how to use creativity tools to achieve advertising effectiveness in organizations. Other specific objectives include to:

1. Determine the influence of brainstorming on achieving advertising effectiveness in organizations.

2. Examine the influence of relationship between Novelty and advertising effectiveness in organizations.

3. Ascertain the impact of relationship between craftiness and advertising effectiveness in organizations.

4. Examine the impact of relationship between humor and advertising effectiveness in organizations. 
INTERNATIONAL JOURNAL OF ACADEMIC RESEARCH IN BUSINESS AND SOCIAL SCIENCES

Vol. 8, No. 7, July 2018, E-ISSN: 2222-6990 @ 2018 HRMARS

\section{Review of Related Literature \\ Conceptualization \\ Creativity}

Creativity is thus often defined as useful novelty or not novelty for its own sake, but novelty that can be applied and add value" (Oldham and Cumming 1996). Amabile proposes that a product will be judged creative to the extent that is a novel and appropriate, useful, correct, or valuables response to the task at hand (Amobile, 1997). Leo Burnett defined advertising creativity as a unrelated things in a manner that is relevant, believable and in good fate" (Blasko and Mokwa 1986). Advertising creativity is the artistic way to combine new and meaningful relationship between unrelated thing in a manner that is relevant, believable, and prevent the product in fresh way (Burnel 1968 and West 2004).

\section{Advertising}

Advertising is defined as "the activity or profession of producing advertisement for commercial products or services". In order to "describe or draw attention to (a product, service, or event) in a public medium in order to promote sales or attendance" Research testifies that advertising has a direct effect on firm sales, profit, value, brand equity, (Joshi and Hanssens, 2004).

\section{Conceptual Framework Brainstorming}

The word brainstorming" has taken on a variety of popular meanings. For some it means simple to get together and have a casual discussion in order to crime up with a few ideas. Some believe that the term brainstorming is the same thing as idea generation. In other words, brainstorming is a universal treatment (the only way to be creative) or synonymous with the entire creating process. During a recent conference, one National science foundation official indicated that we all know that brainstorming as "cerebral pop corn" Nothing more than a crapshoot" or as a leading international authority on the direct teaching of creative thinking indicated (De Bono 2012), while the term Brainstorming" may be widely diffused, people hold various a conflicting meaning of the term. Different many professionals work with individuals, groups, and organizations to educate and nurture creative abilities and skills. Brainstorming has specific and more technical definitions. Osborn (2011), defined brainstorming as a means to come up with a few ideas, his aims was not merely the generation of ideas, but to encourage everyone to better apply their imaginations to challenges and opportunities.

Lamm and Trommsdorff (2013) opine sixteen studies and found that most of the brainstorming research utilized a similar experimental paradigm and statistical analysis. Stein (1999) provide comprehensively the theory, guideline and outcome of brainstorming research. Jablin and Serbold (2001) identify studies in order to primarily address the question of individual superiority over groups when brain forming. Ruback, Dablos and Hopper (2011) consider previous reviews but focus that attention upon examining the interaction process of brainstorming groups in advertising organizations. Taylor, Berry and block (1958) state that the issue of group participation in brainstorming as having either a facilitating or inhibiting effect on creative thinking. The findings of the study indicated that individuals operating alone and using the brainstorming procedure generated more ideas than groups using the same procedure. 
INTERNATIONAL JOURNAL OF ACADEMIC RESEARCH IN BUSINESS AND SOCIAL SCIENCES

Vol. 8, No. 7, July 2018, E-ISSN: 2222-6990 @ 2018 HRMARS

\section{Novelty}

The researchers in the field generally agree that at least one fact must be "Novelty" (also referred to all "Originality" divergence" unexpectedly" and Newness (Haberlarid and Dacin 1992; Sternberg and Lubart 1993; Ang and Low 2000; Koslow, Sasser and Riordan 2003; El-Murad and west, 2004). This applies in myriad of disciplines, from art to business. For example, in the fine arts creative artists have been said to exhibit disequilibrium in their works (Ang and Low 2000). In business literature, a creative product is said to be original and the outcome of imaginative thinking that requires a conceptual formation of objects that do not exist (Ang and low 2000). In fact According to some researchers novelty should be the primary criterion considered when deciding a product's creativeness, regardless of other potential positive attributes (Jackson and Messick 1967; white and smith 2001; Koslow, Sasser and Riordan 2003). Within the field of advertising, most definitions of creativity involve an aspect of Newness, unexpectedness or originality (Sterniberg and Lubart 1993; White and Smith 2004). Daniel, Sajeev and Christy (2011) examine the differential effects of advertising novelty and message usefulness, frequently conceptualized as the two major dimensions of advertising creativity on the following variables attitude recall the advertising, attitude towards the brand, brand trust, advertising recall, and brand recall.

\section{Humor}

Organizational member are diverse individuals who use humor in their everyday jobs. Using humor in the workplace is a common ritual that members share in order to alleviate stress to improve creative vision and to bond (Kreps, Herndrn and Ameson 1993) Fry (1994) define humor generally as a "genetic biologic, characteristic of the humor race" that continue to develop in complexity as one gets older and learns more through he/her life. Veatch (1998) argue that "humor is an inherently mysterious and interesting phenomenon when pervades human life". Currently humor is widely vital in any communicative organization both advertising and non-advertising organization in Nigeria, it is thought to gain audience attention and recall includes favourable attitude towards organizational staff and non-staff. In view of scholars some time it is meant to elicit a gentle smile other times to generate belly laughter. Sometimes it is used to generate a click through to the client's site, other times it is on the destination site to build for and linage (Duncan, 1979).

\section{Theoretical Framework}

A model developed to provide the theoretical framework for this study. The general theory of creativity in advertising was anchor significantly on this study. The interface between creativity and advertising include a much broader conceptual domain specifically, it is important to consider creativity in advertising from a number of different perspectives. According to (Sternbery, 1999), Who conceptualized space of general theory in creativity advertising in five major paradigms were he identified, general theory in creativity advertising in five major paradigms were he identified, 
INTERNATIONAL JOURNAL OF ACADEMIC RESEARCH IN BUSINESS AND SOCIAL SCIENCES Vol. 8, No. 7, July 2018, E-ISSN: 2222-6990 @ 2018 HRMARS

Figure: 1 Theoretical based under the Study.

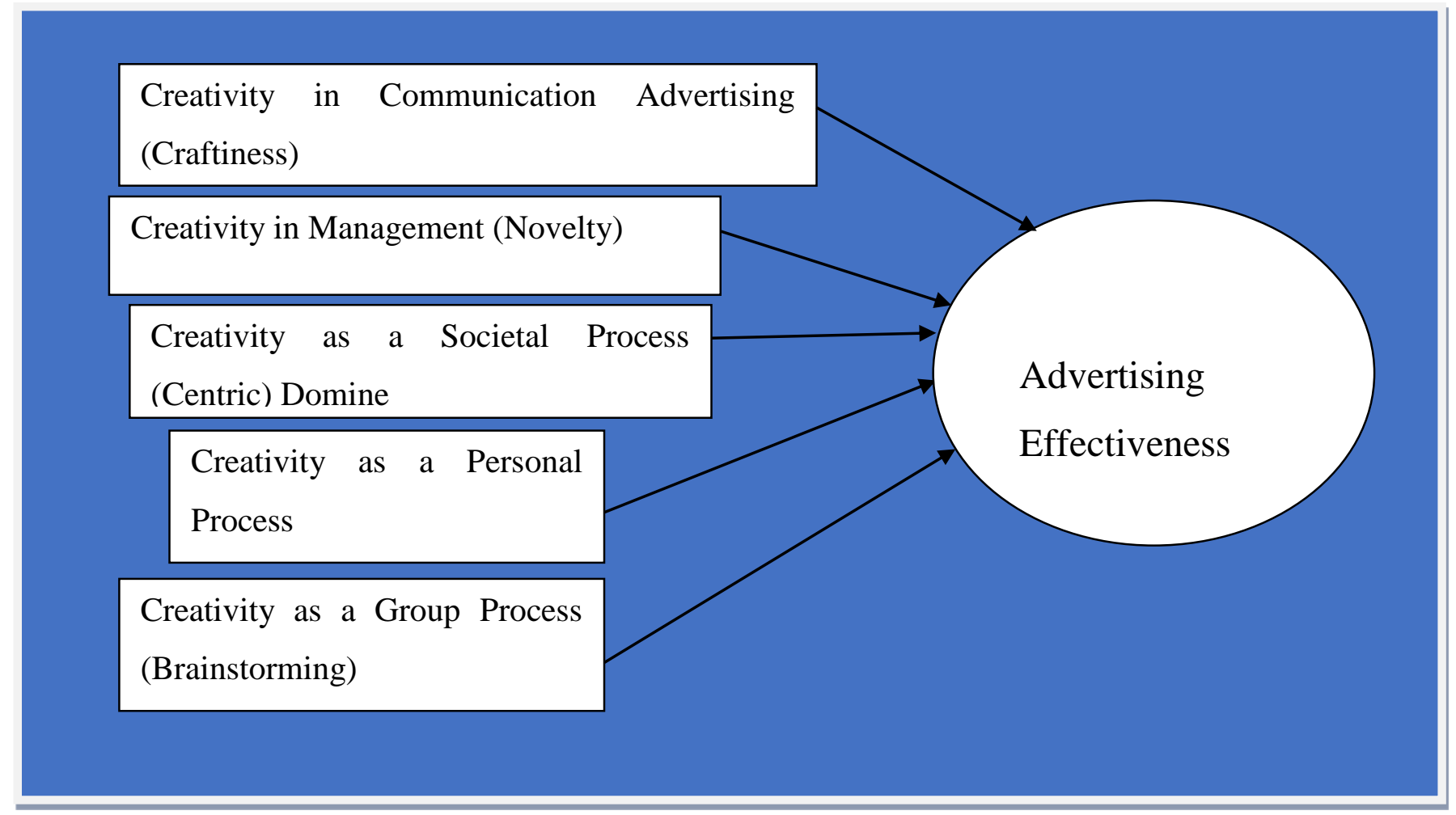

Source: Sternberg (1999) General Theory of Creativity in Advertising.

1) Creativity in communication advertising is a major form of communication between companies and their customers. Issues involves here include how creativity affect persuasion, information processing consumer response and variables interact with creativity to influence advertising effectiveness use creativity to position the image of the company, introduce new products or band extension recommend new usages for companies exciting products, recognize the identify when consumers prefers creative or non-creative advertisement, ii. Creativity in the management: Advertising is an element of the promotional mix and must be carefully managed to maximize sales promotional management issues to creativity include, living, managing and motivating creative personnel, understand and stimulating the creative process, developing creativity strategy and tactics and planning creative advertising campaign, iii. Creativity as a societal process: Advertising has significant effects on society and some of the important ones directly to creativity issues include effects on popular creative advertising as commercial art, teaching advertising and using creative advertisement to educate consumers on important societal issues such as the dangers to drunk driving or how to reduce the risk of Aids. iv. Creativity as a group process: Advertising creativity is usually a product of group collaboration and therefore it is critical to assess how creative ideals are generated in a term setting, creativity issues includes effect to majority/minority influence the role of personal/social identity and group creativity and the factors that facilitate or prevent group members from producing creative ideas, v. Creativity as a personal process: Advertising creativity is processed by individual consumers and can creativity is processed by individual consumers and can have personal ramifications. Issues include advertising as sources of consumer growth, consumer creativity 
INTERNATIONAL JOURNAL OF ACADEMIC RESEARCH IN BUSINESS AND SOCIAL SCIENCES Vol. 8, No. 7, July 2018, E-ISSN: 2222-6990 @ 2018 HRMARS

consumer self-actualization consumer self-concept and the impact of these individual difference variables on the effectiveness creative advertisement.

The general theory of creativity in advertising was discovered to be relevant to this study, because perfection is something humanity cannot attain but, always strive towards, based on this ideology of five major paradigms identified creativity in communications, management, society, groups and individuals. Organizations are determined to experience the adoption of general theory from members of the public's. And once an organization experiences any of these, the general theory comes in handy. And implication point of these general theory is based on modern customers are exposed too many creative advertisement each day in any organization indeed this is probably a major creative interface for marry people theory section identified a number of different ways that advertising creativity is important. Hopefully, as future researchers develop and refine creativity in advertising theory, it will come to be includes in broad review of the construct in modern organizations. As such the model is said to be relevant to this work.

\section{Empirical Studies}

Ahmad (2011) examined the association between creativity advertising and advertising effectiveness in organization in Nigeria. The finding of this study showed that single exposure does not verify the superior performance of creative advertising in terms of recall. brand and advertisement attitude and purchase intent. However, the Application of the three exposure components creative advertisement control develop more significantly favourable brand and advertisement attitude and greater unaided brand recall and control advertisement services. The results of this study in three exposures concluded that creative advertisement were really more effective than conventional advertisements and bestowed value to the advertised brands.

Usmaii (2003) examined create the advertising more effective to influence the audience being targeted in Nigeria organizations. The study mainly concerned with audience belonging from the different cultures. The theory posits that the combination of factors such as humor, medium uniqueness, marketing strategy, national culture, and consumer motives all constitutes the effective adverting in order to persuade the target audience. However, the findings suggested that the framework proposed was quite effective to meet with consumer requirements. The establishment of the advertising creation increases the total sales volume and consumer level of purchase in organization.

Satyendra (2013) examined the impact of Colour on Marketing of Organization. He found out that managers can use color to increase or decrease appetite, enhance mood, calm down customers and reduce perception of waiting time; but today an organization cannot hold its advertisement activities without considering color as- the basic component of the message.

Lyttle (2013) examined the effective use of humor in advertising. According to him based on findings, humor has long been a popular tool of advertising agencies. It has been a controversial one. The analysis suggested that the use of humor was not superior to direct messages. While it can promote message comprehension and improve attitude to the brand (and to the advertisement, it is not related or is sometimes negatively related to purchase probability or actual behaviour but exponent has shown today that it has been found to have little impact on counter arguments, product related beliefs, buying intention experience of distraction or recall of selling points of the customers in organization. 
INTERNATIONAL JOURNAL OF ACADEMIC RESEARCH IN BUSINESS AND SOCIAL SCIENCES

Vol. 8, No. 7, July 2018, E-ISSN: 2222-6990 @ 2018 HRMARS

Figure: 2 Conceptualization Model

The Schematic Model

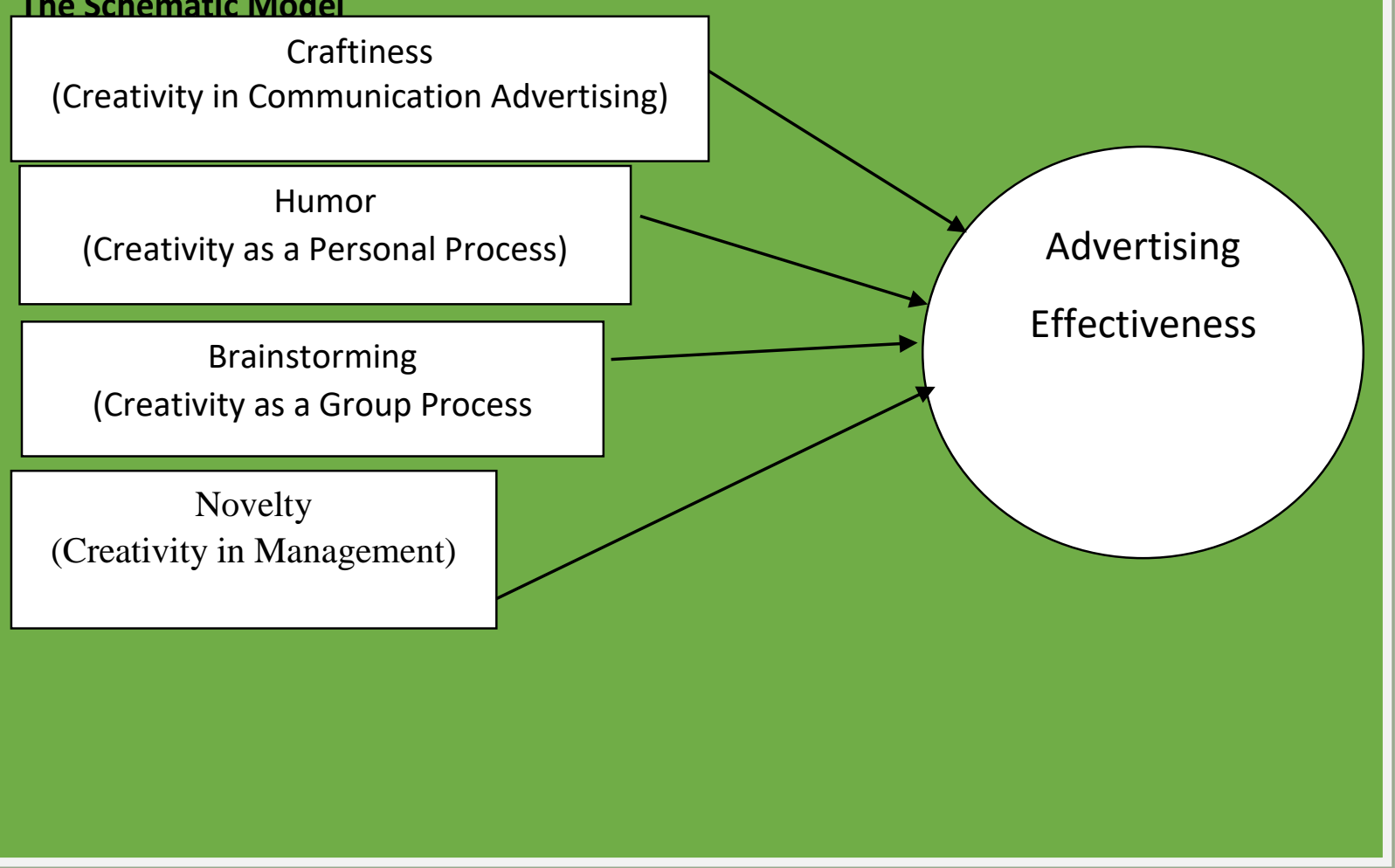

Source: Researchers Own Conceptualization Model

\section{Methodology}

This section on methodology deals with the procedures for collecting and analyzing of data necessary to help identify and solve the problem at hand. This were treated under the following subheading:The research design, population of study, sample and sampling procedure, Area of the study, source of data, instrument for data collection, Administrative of questionnaire, validation of instrument, reliability of instrument and data analysis procedure.

Research Design research is a term used to describe a number of decisions which need to be taken before data collection. Therefore, for the purpose of this study were survey research design was adopted. And survey research involves asking question through questionnaire, collecting and analyzing data gotten from the sample size of the population. The sources of data for this study were done through primary and secondary sources of data, the primary sources of data were got from the copies questionnaire, and observation while secondary sources were also got from extensive review of textbooks from seasoned authors, internet materials and journal publications etc. The population of the study comprises of six (6) Registered Advertising Agencies in Enugu namely Rocana (52), Kite Ideal (15) Reeds and mark (12), Tego (8), Wise craft (12) and down function (15) So, the researcher used six of them which practice both outdoor and indoor advertising programme. The estimated 
INTERNATIONAL JOURNAL OF ACADEMIC RESEARCH IN BUSINESS AND SOCIAL SCIENCES Vol. 8, No. 7, July 2018, E-ISSN: 2222-6990 @ 2018 HRMARS

population for the study consisted of staff with trial of 114 populations. Sample size were determined using Taro Yamane formula to determine the sample size. The formula is stated below as follows:

Where:

$\mathrm{n}=$ The sample size

$\mathrm{N}=$ Total population

$\mathrm{e}=$ Margin error (0.05) level of significance)

$\mathrm{I}=$ Constant

$\mathrm{N} \quad 114$

$\mathrm{n}=1+N(e)^{2}$

$\mathrm{N}=\frac{114}{1+114(0.05)}$

$\mathrm{N} \quad 114$

$n=1 \overline{1+114(0.0025)}$

$\mathrm{n}=\frac{114}{1.285}=89$

$\mathrm{n}=89$

Therefore, the sample size of the study comprises 89 subjects representing $78 \%$ of the entire population of 114 staff. Simple random sampling technique was used to select 89 subjects comprising male and female staff. The simple random sampling was used to ensure equal opportunity participation of respondents and to prevent bias in the selection process. Questionnaire was developed as instrument for data collection. Validity and reliability of instruments, the instruments for data collection undergo scrutiny and approval by the supervisor and other expert in the Department of Marketing Niiamdi Azikiwe University, Awka. The focus was to check whether the items in the instrument are relevant, clearly stated and capable of eliciting the right responses from the respondents. The standard of the questionnaires measure was improved based on the suggestion of the experts. The reliability analysis for this research was carried out using Cronbach's Alpha. Decision Rule: If the calculated Cronbach's alpha is significantly greater than 0.7 , the questionnaire is deemed to have excellent stability and consistency. (Reference to Appendix 2). Data were analyzed using both descriptive and inferential statistical tools employed in this study.

\section{Data Presentation and Analyses}

This section outlined, we are concerned with the analysis of the answers to the questions in the questionnaire administered to the respondents. The use of table was being adopted to clearly show the responses obtained in each question of the questionnaire and the research hypothesis from section one were tested with the use of analysis of multivariate regression. According to the table below 89 questionnaire were distributed to the staff of selected advertising firms in Enugu State, A total of 70 were competed and returned and 19 were not returned. Therefore, the total of 70 questionnaire were be used for the analysis. 
INTERNATIONAL JOURNAL OF ACADEMIC RESEARCH IN BUSINESS AND SOCIAL SCIENCES

Vol. 8, No. 7, July 2018, E-ISSN: 2222-6990 @ 2018 HRMARS

\section{Descriptive Statistics Regarding Using Creatively Tool to achieve advertising effectiveness in organizations.}

Table 5

\begin{tabular}{|c|c|c|c|c|c|c|c|c|}
\hline Variables & Agree & $\begin{array}{l}\text { Strongly agree } \\
(\%)\end{array}$ & Disagree & $\begin{array}{l}\text { Strongly } \\
\text { disagree }\end{array}$ & $\begin{array}{l}\text { Total } \\
\text { number }\end{array}$ & Percentage & Mean & S.D \\
\hline Brainstorming & $33(47.1)$ & $20(28.6)$ & $9(12.9)$ & $8(11.4)$ & 70 & 100 & 17.5 & 10.1 \\
\hline Novelty & $35(50)$ & $17(24.3)$ & $8(11.4)$ & $10(14.3)$ & 70 & 100 & 17.5 & 10.6 \\
\hline Humor & $35(50)$ & $18(25.7)$ & $9(12.9)$ & $8(11.4)$ & 70 & 100 & 17.5 & 10.8 \\
\hline Craftiness & $35(50)$ & $18(25.7)$ & $7(10)$ & $10(14.3)$ & 70 & 100 & 17,5 & 10.9 \\
\hline $\begin{array}{l}\text { Advertising } \\
\text { Effectiveness } \\
\text { (dependent) }\end{array}$ & $32(45.7)$ & $22(31.4)$ & $9(12.9)$ & $7(10)$ & 70 & 100 & 17.5 & 10.2 \\
\hline
\end{tabular}

\section{Source: Survey Work, 2018}

From table 5 above, 33(47.1\%) respondents agree, 20(28.6\%) strongly agree that right group determine creative thinking while $9(12.9 \%)$ disagree and $8(11.4 \%)$ strongly disagree that right group does not determine creative thinking. With data evidence shows that right group determines creative thinking. Then better originality attract attention 35(50\%) agree and $17(24.3 \%)$ strongly agree while $8(11.4 \%)$ disagree and $10 .(14.3 \%)$ strongly disagree that Novelty initiate better originality which the data shows evidence positively. In contrary, humor as an instrument of creating awareness. 35(50\%) respondents agree and $18(25.7 \%)$ strongly agree while $9(12.9 \%)$ disagree and $8(11.4 \%)$ strongly disagree that humor is a means of awareness creation. But with data evidence it is. Then craftiness $35(50 \%)$ respondents agree and $18(25.7 \%)$ strongly agree while $7(10 \%)$ disagree and $10(14.3 \%)$ ) strongly disagree that well-craftiness demonstrate high impact on advertisement. But with evidence shows on data it has high impact. Then concerning dependent variables known as advertising effectiveness shows that 32(45.5\%) agree, 22(31.4\%) strongly agree while $9(12.9 \%)$ disagree and $7(10 \%)$ strongly disagree that well- craftiness impact positively in advertising.

\section{Multivariate Regression Analysis}

Multivariate regression creates a one - to - many predictive relationships among variables. Multivariate regression enables you to relate one dependent variable to multiple independent variables you have derived from surveys or measurements. This type of data analysis helps us to search for the effects of your data on a related condition, or predict a condition based on other related observations. It can reveal patterns that help you understand your customers and enhance the market for your products.

$Y_{i}=\beta o+\beta_{1} X_{i}+\beta_{2} X_{i}+\beta_{3} X_{i}+\mu$

Where $Y_{i}$ is the dependent variable 
INTERNATIONAL JOURNAL OF ACADEMIC RESEARCH IN BUSINESS AND SOCIAL SCIENCES

Vol. 8, No. 7, July 2018, E-ISSN: 2222-6990 @ 2018 HRMARS

$B_{0}$ is the constant term,

$\beta_{1} \beta_{2} \beta_{3}$ are the parameters or the estimators;

$X_{i}$ 's are the explanatory variables and $\mu$ is the error term

Table 7: Multivariate Regression Analysis Result

\begin{tabular}{|l|l|l|l|l|l|l|}
\hline Equation & Obs & Farms & RMSE & "R-sq." & F & P \\
\hline advertising eff & 70 & 5 & 464250 & 0.9962 & 2171.586 & 0.0000 \\
\hline
\end{tabular}

\begin{tabular}{|c|c|c|c|c|c|}
\hline advertising eff & Coef. & Std. Err. & $T$ & $P>t$ & \begin{tabular}{|ll}
$95 \%$ & Conf. \\
Interval & \\
\end{tabular} \\
\hline braiiistorming & 33.32655 & 4.363215 & 7.64 & 0.000 & $\begin{array}{l}24.44952 \\
42.20358\end{array}$ \\
\hline novelty & .6388039 & .1455949 & 4.39 & 0.000 & \begin{tabular}{|l|}
3425889 \\
.935019
\end{tabular} \\
\hline humor & 2.352867 & .4863198 & 4.84 & 0.000 & $\begin{array}{l}1.363442 \\
3.342292\end{array}$ \\
\hline craftiness & .6366009 & .1554453 & 4.10 & 0.000 & \begin{tabular}{|l}
.320345 \\
.9528569
\end{tabular} \\
\hline _C011S & $\mid-120742.4$ & 95859.18 & -1.26 & 0.217 & \begin{tabular}{|l|}
-315769.4 \\
74284.54
\end{tabular} \\
\hline
\end{tabular}

Brainstorming: This variable is the most effective among the creativity tool to achieve advertising effectiveness as the coefficient is 33.32655 which mean that $1 \%$ increase in the use of brainstorming will result a whopping 33.33\% increase in achieving advertising effectiveness 011 averages.

Novelty: This variable is also effective as a creativity tool in achieving advertising effectiveness. The coefficient .6388039 means that a unit increase in making a better originality of advertising (novelty) will on average, increase advertising effectiveness by 0.63 units.

Humor: This variable also play a very crucial role in achieving advertising effectiveness as a creativity tool in advertising industries. The coefficient 2.352867 means that percentage increase in enhancing service credibility in advertising industry will go a long way to increase advertising effectiveness by $2.35 \%$.

Craftiness: This variable also plays a very crucial role in achieving advertising effectiveness as the coefficient value is .6366009 . This means that a unit increase in the acquisition of knowledge and skill among the staff will bring about an increase in advertising effectiveness by 0.64 units.

The constant term: This is the intercept value which is the value of the advertising effectiveness when all the creativity tools are kept constant. The negative value of the constant term means that the creativity tools included are advertising effectiveness leading. This simply means that advertising effectiveness will likely to fall by 12 units when all the creativity tools are kept constant. 
INTERNATIONAL JOURNAL OF ACADEMIC RESEARCH IN BUSINESS AND SOCIAL SCIENCES

Vol. 8, No. 7, July 2018, E-ISSN: 2222-6990 (C) 2018 HRMARS

\section{Testing of Hypothesis}

The hypotheses of our study will be evaluated with the aid of $t$ - test. Decision rule is that if the probability value is less than 0.05; reject the null hypotheses and accept significance, otherwise accept the null hypotheses and reject significance (if it is greater than 0.05 ).

\section{Hypotheses One}

This is the proposition that there is no significant relationship between brainstorming and advertising effectiveness.

(I) [Advertismg_eff] brainstorm $=0$

$F(1,33)=58.34$

Prob > F - 0.0000

Since the probability value is less than 0.05 , we reject the null hypotheses, concluding that there is significant relationship between brainstorming and advertising effectiveness. And this relationship is very strong which is depicted by the $t$ - test as 58.34 .

\section{Hypotheses Two}

This is the proposition that there is no significant relationship between novelty and advertising effectiveness.

(2) [ Advertising eff] novelty $=0$

$F(1,33)=19.25$

Prob > F - 0.0001

Similarly, the probability value is less than 0.05 ; we reject the null hypotheses, concluding that there is significant relationship between novelty and advertising effectiveness. And this relationship is fair which is depicted by the $\mathrm{t}$ - test as 19.25.

\section{Hypotheses Three}

This is the proposition that there is no significant relationship between craftiness and advertising effectiveness.

(3) [Advertising_eff $\mid$ craftiness $=0$

$F(1,33)=16.77$

Prob $>F=0.0003$

Also, the probability value of craftiness is less than 0.05 ; we reject the null hypotheses, concluding that there is significant relationship between craftiness and advertising effectiveness. This relationship is fairly significant which is depicted by the $t$ - test as 16.77 .

\section{Hypotheses Four}

This is the proposition that humor adoption does not increase advertising effectiveness in organization.

(4) [Advertising_eff] humor $=0$

$F(1,33)=23.41$

Prob $>\mathrm{F}=0.0000$

Similarly, the probability value is less than 0.05 ; we reject the null hypotheses, concluding that humor adoption increases advertising effectiveness in organization. This relationship is also very significantly strong which is depicted by the $\mathrm{t}$ - test as 23.41 . 
INTERNATIONAL JOURNAL OF ACADEMIC RESEARCH IN BUSINESS AND SOCIAL SCIENCES

Vol. 8, No. 7, July 2018, E-ISSN: 2222-6990 ㄷ 2018 HRMARS

From the foregoing analyses, we discover that all four creativity tool used in analyzing the achievement of advertising effectiveness are statistically equal to zero; hence they are significant.

\section{Summary of Findings}

- $\quad$ The study revealed that there is a high significant and effective relationship established by brainstorming towards achieving advertising effectiveness as its $t$ - test value is 58.34 and the coefficient value is 33.33. Initial description of brainstorming claimed that it is by reducing the amount of criticism from self and others during this creative process, a group of staff could produce better result in terms of quantity and quality advertising programme. This is consonance with the findings of Osborn (2011).

- $\quad$ The study also finds that humor as a creativity tool has a fairly significant relationship with the achievement of advertising effectiveness as its $t$ - test value is 23.41 and the coefficient value is 2.35 from the statistical table. Humor as a facet of creativity, related to the divergent qualities of advertisement. This is also in agreement with findings of Smith and Vang (2004)

- In comparison with the other variables, we deduce that novelty and craftiness are weak but also significant and cannot be despised in achieving advertising effectiveness as the constant term depicts a negative sign (-12.074) from the statistical table. In the evidence shows that novelty is an attractive criteria to explain creativity Besemer and Treftinger (1981). While and smith (2001) have built on this tradition and included well craftiness alongside measures of differences in creativity judgment between advertising professionals.

\section{Conclusion}

The study investigated using creativity tools to achieve advertising effectiveness in organizations. The finding of the study revealed that brainstorming and humor have a strong association with advertising effectiveness. Therefore, it is concluded that organizations should strengthen on these two major tool for achieving advertising effectiveness in organizations.

\section{Recommendations}

1. The advertising environment should be conductive to enable the staff bring in their best in terms of creativity during the period of brainstorming. Furthermore, professionals should be employed to replace quacks, charlatans and interlopers in these areas. So that they can compete favourably in the market.

2. There should be teamwork among the staff in advertising outfits. A tree, they SSL cannot make a forest, so the managers need the support of his subordinates to succeed. On his own part, the managers should ensure that the Staff who is talented in the area of creativity should fix in creative department.

3. Bad products and services should not be advertised or packaged. However, excitement can be created around dull product features. 
INTERNATIONAL JOURNAL OF ACADEMIC RESEARCH IN BUSINESS AND SOCIAL SCIENCES

Vol. 8, No. 7, July 2018, E-ISSN: 2222-6990 @ 2018 HRMARS

\section{References}

Ahmad, R.C (2011). Creativity in Problem-solving and Planning: A Review, "European Journal of operational Research, 7,(1), 1-13.

Aliede J.E (2005) This Challenge of Responsible Practice of Promotional Advertising in Nigeria: In Nwosu, Aliede and Nsude (edition) Communication. One Course. Many Professionals, Enugu: prime publisher Ltd.

Amobile, .T.M. (1997), Entrepreneurial Creativity through Motivational Synergy: Journal of Creativity behavior. 31,(I): 18-26.

Angel, T (2007). This Advertising Creativity Cube: Conceptualization and Initial Validation: Journal of this Academy of Marketing Science, 35,(1), 220-252

Ang, S.H and low, Y.M (2000). Exploring this dimensions of Advertising creativity: Psychology and Marketing Research, 33(may), 174-187.

Arden, .P. (2004) It's Not How Good You Are, It's How Good You Want To Be, New York: Phaidon.

Blasko, k., and Mokwa, G (1986). Creativity in Advertising: A Journal Perspective: Journal of Advertising, 15 (4),43-72.

Besemor .S. and Trefinger, D.J. (1981). Analysis of creative products: Review and synthesis" Journal of creative behavior, 15,(3), 156-78.

Burnel, F.F. (1968). Message Order Effects and Gender Differences in Advertising Persuasion: A Developmental Study among College Studies: Journal of Advertising, 43(3), 380-341

Cummings, A, and Oldham, G.R (2013). Enhancing Creativity: Managing Work Contexts For this high potential Employee: California a Management Review, 40(1): 22-38.

Daniel, D., Sajeev, H., and Christy, G (2011), The Differential Effect of Advertising Novelty and Message Usefulness On Brand Judgment. Journal of Advertising, 40,(3), 5-17.

De Bono. E. (2012).De Bono's Thinking course, facts and on file, New York.

Duncan, E.P (1979). Humor in Advertising: A Behavioural Perspective: Journal of the Academy of Marketing Science 7 (4): 385-306

EL-Murad, J., and West, D.C (2004). The Definition and measurement of Creativity: What Do We Know: Journal of Advertising Research (June), 188-201.

Fry, J. (1994). Work Place Creativity: Published by J. Ossey: Bas 31 Jan 2011 Do 1: 1010021 erl. 3910210103.

Haberland G.S and Dacin P.A (1992). The development of a measure to Assess viewers' judgment of the creativity advertisement: A preliminary study: Advance in consumer Research; 19,(2),317- 825 .

Halinen .A (1997). Relationships Marketing in Professional services: A study of Agency- Client Dynamics in the Advertising sector: London: Routledge.

Jablin M., and Serbold D. R. (2001). Implications for Problem-Solving Groups of Empirical Research on "Brainstorming: A Critical Review of the Literature, Southern Speech Communication Journal 43,(1), 327-356.

Jackson, P.W., and Messick, S. (1967). The person, The product, and The Response: Conceptual problems in the Assessment of creativity: Journal of personality, 33,(2),309-329.

Joshi, .A. and Harissens, .A (2004). Advertising Spending and Market Capitalization: Working Paper No, 388, Marketing Studies Center, Anderson School of Management, University of California, Los Angeles. 
INTERNATIONAL JOURNAL OF ACADEMIC RESEARCH IN BUSINESS AND SOCIAL SCIENCES

Vol. 8, No. 7, July 2018, E-ISSN: 2222-6990 @ 2018 HRMARS

Kreps J. and Starberg, .R. (1993) This International Handbook on Creativity, New York, NY: Cambridge University Press.

Kover A.J (1995). Copywrites Implicit theories of Communication: An Exploration: Journal of consumer Research 21,(3),596-611.

Koslow, S., Sasser, S., and Riordan, E.A (2003). What is Creative to Whom and Why: Perceptions in Advertising Agencies: Journal of Advertising Research (March) 96-I 10

Lamm, H. and Trommsdorff, G. (2013). Group Verses Individual Performance on Talks Requiring Ideational Proficiency (Braiiistorming). European Journal of Social Psychology 3 (1573)361387.

Lyttle, O.H (2013). Humorous Communication: finding a place for humor in communication research", communication theory, 12,(4), 423-45.

Matthew, .K., and Ibikunle .A (2012). The Impact of ICTs on Banks: International Journal of Advanced Computer Science and Application: Covenant University Ota, Ogun State, Nigeria: 3,(9), 9-13.

Oldham, G.R., and Gumming .A (1996). Employee Creativity Personal and Contextual Factors" Academy of Management Journal 39(3):607-635

Satyendra .S. (2013), Impact of Colour on Marketing Journal of Marketing, University of Winnipeg, Canada, 44,(6), 783-789 Emerald Group Publishing Limited 00251747.

Shelley C.E and Gilson L.L (2004). A Little Creativity Goes A Long Way: An Examination of Teams Engagement in Creative Processes. Journal of Management. 30,(1), 453-479.

Osborn .A. (2011). Applied Imagination, Scribner's, NY,USA.

Starnberg, R.J. (1999). Investing in Creativity: American Psychologies, 517, 677-688

Ruback R.E., Dablos, F., and Hopper, X. (2011). Toward a general theory of creativity in advertising: Examining the Role of divergence". Marketing theory, 4: 31, 31-57.

Sternberg, R.J and lubart T.I (1993). Investing in Creativity". American psychologist 57:7,677-688.

Stewart, D.W (1992). Speculation on the Future of Advertising Research: Journal of Advertising 21,(3):1-18.

Stein M.I (1999). Creativity in Handbook of Personality Theory and Research, Ed. E.F Borgalta W.W Lambert. Chicago. Rand McNally.

Taylor D.W, Berry P.C and Block C.H (1958). Does Group Participation When Sing Brainstorming Facilitate or Inhibit Creativity Thinking.

Tellis, G.J (1998), Advertising and Sales promotion Strategy Massachusetts: Addison-Wesley.

Usman .M. (2003). Creation of effective Advertising in the persuasion of target announce: Journal of Advertising Research, 2,(1), 20-33.

Veatch .T. (1998). A theory of humor: Humor: International Journal of humor Research, 11,(2), 161215.

West, D.C (1993). Gross-National Creative Personalities, Processes, and Agency Philosophies" Journal of Advertising Research, 33(5):53-62.

West, D (2004). The Definition and Measurement of Creativity: What Do we know? Journal of Advertising Research, 44,(2), 12-23

White A and Smith B.L (2001). Assessing Advertising creativity using the Creative product semantic Scale: Journal of Advertising Research, 41,(6), 2734.

White A and Smith B.L (2004). Assessing Advertising creative using the creative product semantic scale: Journal of advertising Research, 13,(1), 3-20.

Zinkha, G.M (1993). Creativity in Advertising: Creativity in the Journal of Advertising, 22,(1), 1-3. 